\title{
Impact Investing Innovation - Bringing Together Public, Private, and Third Sectors to Create Greater Value: The Case of the Public Private Partnership Initiative for the New Public Hospital of Treviso
}

\author{
Filippo Addarii, Fiorenza Lipparini, Francesca Medda \\ 1. The Case: impact investing strategy in the PPP for the new hospital of Treviso
}

The Public Private Partnership (PPP) for the new hospital of Treviso is the first case in Europe of a large infrastructural project in which social impact investing principles have been applied in the design of the project financing, construction and operation phases of the development (EIB 2017). After a presentation of the PPP structure and the impact investing strategy giving the reader the essential background information, we will use the 'Shared Value' framework developed by Michael Porter and Mark Kramer (Porter and Kramer 2011) to analyse the achievements of this project against an international trend fostering a transformation of capitalism towards a new relationship with society and value creation beyond shareholders' interests. The Shared Value theory captures a trend within the private sector, echoed in the other sectors and, at the same time, opens the way for a better alignment between public and private interest. So, it helps to assess the value of the Treviso project and the original contribution of its analysis. On the other hand, this case proves that 'Shared Value' has a fruitful intuition at its core, but the theory is still a work in progress and requires deeper research as well as innovation in the practice. Porter and Kramer have been criticized for their reductionist interpretation of the relationship of business and society (Crane et al. 2014).

The authors of the paper has been directly involved assisting the private sector partner of the PPP in devising the impact investing strategy of the project and its implementation. This gives a unique vantage point in the analysis of the case that brings together research and practice, and contributes to the advancement of the impact investing field in practice and policy.

\subsection{PPP for the new hospital in Treviso}

In December 2015, the concession contract for the new hospital of Treviso was awarded to Ospedal Grando S.p.A. (OG), the SPV (Special Purpose Vehicle) established by Lendlease (through its subsidiary Finanza e Progetti) together with the other financial and industrial partners. ${ }^{1}$ LendLease is an Australian multinational corporation specialised in urban regeneration and infrastructural projects. It is a developer and investor that designs, finances and manages its projects in partnership with public institutions.

Treviso is a wealthy small town in Veneto (North East of Italy) and an industrial hub hosting international brands like Benetton and Geox. Investing for the renewal and upgrade of its social infrastructures is strategic for keeping its competitive advantage internationally. The hospital serves all the community in the province of Treviso which has a population of up to

\footnotetext{
${ }^{1}$ See Figure 2
} 
$1 \mathrm{~m}$ people after the recent restructuring of the regional NHS service. Treviso is the main hospital in the province offering specialist services.

The concession contract for the new hospital demands an extensive renewal and the partial refurbishment of the hospital, and the provision of asset management and facility management services for 21-years from the signature of the concession. The construction part aims at rebuilding a large portion of the hospital maintaining the overall surface of 160 '000 sqm (with 1000 beds) with an upgrade of core and intensive health care services including day surgery, and a general technological enhancement. The new and refurbished buildings will comply with the latest safety and anti-seismic structural regulations, as well as higher energy standards allowing for savings and $\mathrm{CO} 2$ emissions reduction. The goal is to make the hospital of Treviso a regional hub that will serve as a model of the whole health service in the region as stated by Luca Zaia, the president of the Veneto Region at the ceremony to lay the first stone on 17th June 2017 (Wolanski 2017).

We briefly review the corporate, economic and financial structure of the PPP to put the development of the impact investing strategy into context. OG is a company limited by shares registered in Italy and $80 \%$ owned by Finanza e Progetti of which Lendlease holds a $50 \%$ share. Originally Finanza e Progetti shareholders were Lendlease (49\%) and Palladio Finanziaria (51\%) the latter being an Italian investment company. In 2015 there was a change in the shareholding structure. Palladio sold its shares in Finanza e Progetti that were purchased by Lendlease and then $50 \%$ sold to Servizi Italia, a new industrial partner, which provides laundry and sterilization services for hospitals. The other $20 \%$ ownership of OG is held by several industrial partners: SIRAM (10\%); Carron Italy (2.5\%); Bilfinger SE (2.5\%); Tecnologie Sanitarie (2.5\%). The Construction subsidiary of Lendlease Construction also has $2.5 \%$ shares. In Italy, it's mandatory for the economic operator in charge of PPP contracts to include industrial partners which deliver works and services as shareholders of the SPV. The PPP for Treviso hospital is the first case in the country in which the leader and majority shareholder is a pure developer and investor, not a constructor - an element that explains the attention for innovative financial instruments hence impact investing.

Figure 2 summarizes the complexity of the PPP structure and the tight collaboration between public and private partners. The upper part illustrates the corporate structure of the PPP: the flow of equity and capital. The bottom part of the figure summarizes the services that OG provides to the public authority (identified as the Hospital Trust) and contractual relationship with all industrial partners. Lendlease acts as Project Manager whilst construction is delivered by Bilfinger SE and Carron Italy via an Engineering, Procurement, and Construction (EPC) contract. The other services are design and facility management. They include energy supply, laundry, cleaning, catering, building maintenance, purchasing and maintenance of medical equipment, and management of tenants i.e. all commercial activities within the hospital premises such as bar, restaurant, shopping, units and car park. These are operations which are essential for an effective functioning of the hospital and to serve staff and users. They are also the source of income to repay investors. However, health services which are the core mission of a hospital, are excluded from the PPP. The public authority is in charge of them. 
Figure 2: Corporate, economic and financial structure of the PPP for the new hospital of Treviso ${ }^{2}$

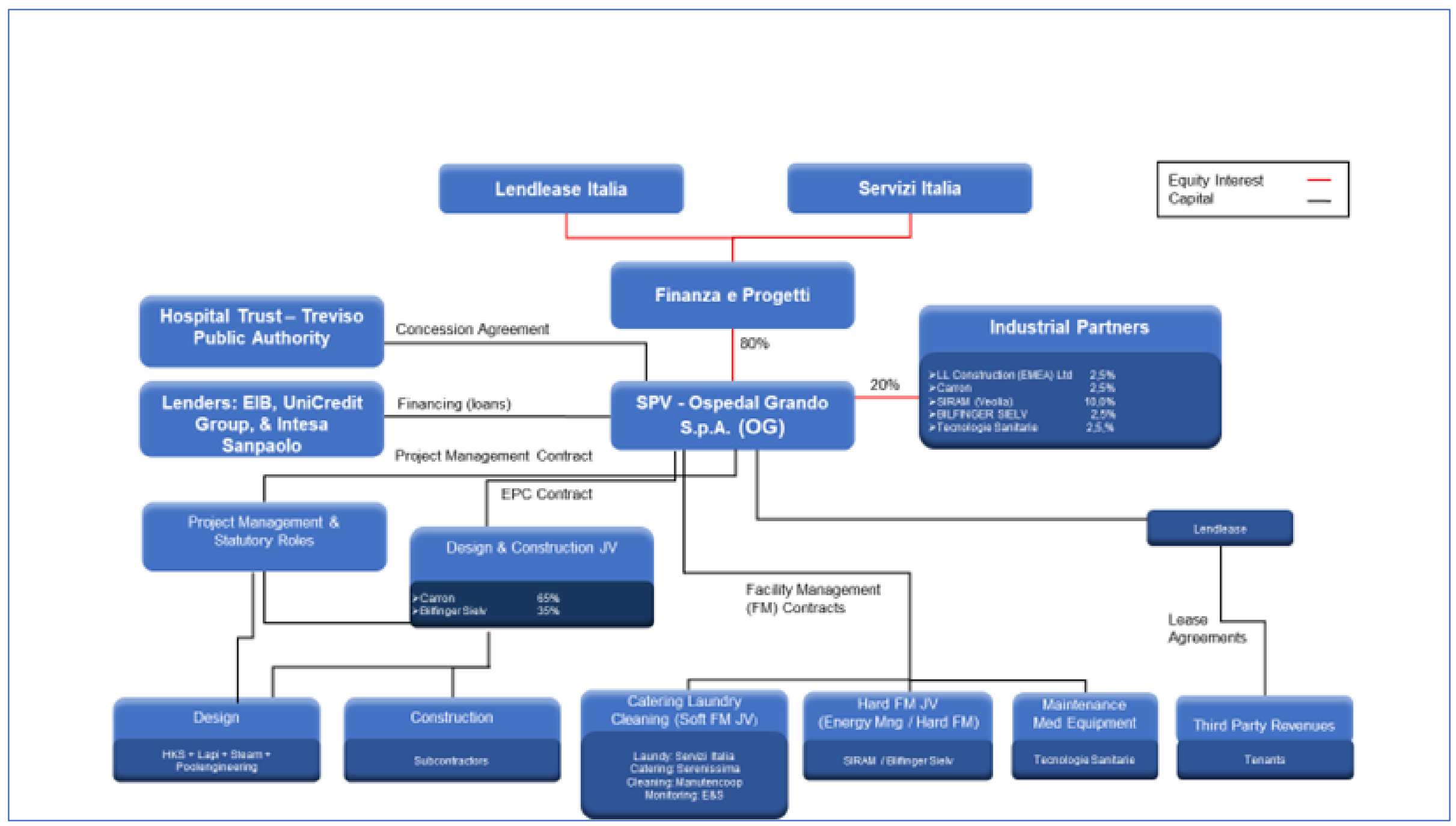

${ }^{2}$ Author's elaboration based on Lendlease's internal documentation 
The finalization of the concession contract was a long journey started in 2012 when OG won the public tender and was awarded the preferred bidder status. But it took until 2015 to finalize the bureaucratic itinerary and start the final negotiation. Public authorizations, further administrative checks, and a law suit led by defeated competitors delayed the process for three more years. This exemplifies the main problems with the Italian system that ultimately drives uncertainty about time and costs for public projects, and discourages international investors and operators. In this project, more than $50 \%$ of the equity invested by the private partners was absorbed in the pre-construction phase at full risk of the private party. The ability of OG to minimize the additional costs generated by the delays in the approval process has been essential for the positive outcome of the project, though the inefficiencies in such a process increased costs and wasted public resources. The ultimate results are a reduction in international competitiveness, market efficiency and innovation. ${ }^{3}$ Paradoxically such a challenging environment forces both the public and private partners to devise new solutions as this case demonstrates. ${ }^{4}$

When, in December 2015, OG finally confirmed the concession contract these were the financial terms: $250 \mathrm{~m}$ euros total value of the investment of which $124 \mathrm{~m}$ from the public sector and $126 \mathrm{~m}$ from the private sector. European accounting rules require more than $50 \%$ of the capital investment to be borne by the private sector for the project to be considered a PPP. This is a condition for the public sector to account the investment off balance sheet and avoid the limits imposed by the European Growth and Stability Pact on public indebtment one of the main reasons for the local authorities to opt for a PPP instead of the ordinary public procurement process (Vecchi and Leone 2016). OG has invested $20 \mathrm{~m}$ euros in equity and sourced $80 \mathrm{~m}$ euros from the debt market. ${ }^{5}$ The other financial resources are generated by the project itself by the provision of services. Several options were considered and a bank loan was deemed to be the most efficient, mainly because of the interest rates that at the time were close to zero, and the flexibility that the loan offers compared to other financial instruments such as project bonds. Banks provided the loan and the financial closing was reached in July 2017: 27m euros by UniCredit Bank Group (the Lead Arranging Bank), 24m euros Intesa Sanpaolo (of which $6 \mathrm{~m}$ by Banca Prossima, Intesa's subsidiary bank specialised in credit to the third sector), 29 m euros European Investment Bank (EIB). EIB has also financed $36 \mathrm{~m}$ euros to the ULSS Treviso (the NHS Agency of Treviso Province) leading on the public sector side of the PPP.

\subsection{Impact investing strategy of the PPP for Treviso hospital}

\footnotetext{
${ }^{3}$ Elaboration of the author based on interviews with Andrea Ruckstuhl (President of OG and CEO of Lendlease Italy) and Francesco Mandruzzato (CEO of OG and Head of PFI at LendLease Italy)

${ }^{4}$ Those new solutions are not always within the legal boundaries and the sector has been undermined by misdeed and financial scandals.

${ }^{5}$ Both figures are approximations due to the complexity of project finance but reflect the order of magnitude (source: Francesco Mandruzzato)
} 
In February 2016 Ospedal Grando S.p.A. (OG) contracted PlusValue (PV) a London-based research and consultancy company specialised in social impact strategies, to provide assistance in devising a strategy for social impact investing. Lendlease, leader of OG shareholders, was interested in testing the possibility to develop a social impact bond or similar financial instrument to source $80 \mathrm{~m}$ euros debt finance. The inspiration came from the UK although it had never been applied to infrastructural projects.

The rationale underpinning the choice was to create and sell a saving product to households and stakeholders in Treviso to finance the $80 \mathrm{~m}$ debt for the hospital. Families and institutions of the local community would make a good investment and, at the same time, finance the upgrade of the infrastructure that they would use in the future. It would be a win - win situation. Obviously, OG expected investors to accept a lower financial return compared to the market rate - the difference being a trade-off for the public value: the upgraded hospital complemented by the commitment from OG to invest $100 \%$ of generated savings in initiatives with a clear and measurable positive impact on the community. This was an original proposal that would apply the principle of impact investing to project bonds which, in countries like the US, are usually used to finance infrastructural projects.

However, these are just speculations because this proposal could not be implemented. Figure 3 illustrates the structure of the impact investing strategy as it was devised at the beginning. The initial structure was simple - reflecting the same simplicity of the Shared Value theory that we review below - but did not take in consideration the complexity that emerged as it had to be finalized and approved by all parties involved. OG was required by contract to have certainty on the full amount of debt capital and precise price - something that a project bond could not guarantee and no bank was ready to write off capital and price in case the sale of bond hadn't reached the targets. The bank Natixis would have done it but at market rates thereby defeating the purpose of the impact investing strategy.

The solution came instead from the European Investment Bank when, in 2016, it offered to join the financing of the project in a club deal with the other banks. EIB took a leading role in relaunching investment in infrastructural projects following the global financial crisis started in 2008, especially through the Juncker Plan for strategic infrastructural investments. The EIB was willing to invest directly in a social infrastructure project in Italy. In the past, the bank did not invest in social infrastructures like hospitals and, certainly, did not do it directly, instead lending capital to national banks. ${ }^{6}$ The combination of the financial crisis that triggered a dramatic drop in public investment in social infrastructures, and the launch of the Juncker Plan changed EIB's lending strategy.

The collaboration with EIB made the social impact investing strategy possible because the European bank lends at the lowest rate in the market significantly reducing the cost of lending compared to any other commercial bank. OG saves 90 basis points $(-0.9 \%)$ on the interest cost of the debt - compared to the market price made by UniCredit, the leading arranging bank, and shared by Intesa Sanpaolo and Banca Prossima, the other commercial banks in the club deal. Moreover, further savings are made on the upfront and commitment fees. At the

\footnotetext{
${ }^{6}$ Interview with Lendlease's senior management
} 
financial signing on July 2017, OG has realized 1.8 m euros in total savings thanks to EIB loan. ${ }^{7}$ At the same time the partnership with EIB has become a validation of the social impact investing strategy vis-à-vis the other banks and public sector partners. The Juncker Plan, for the first time, included 'societal impact assessment' in the investment policy criteria of the EIB (Lipparini et al. 2015) and the bank has acknowledged that the project in Treviso is the first funded by the bank with an explicit commitment to use derived benefits for social impact investing (EIB 2017).

The portion of the debt leveraged for the impact investing strategy could have been greater if all banks had taken part. The commercial banks were not able to offer a discount below the market price. They could have done it if they also had borrowed the capital from EIB. Doing so they would have benefited from price on the cost of capital below the market rate and could have transferred the savings - partially or entirely - to the impact investing vehicle. However, this option was not implemented due to the risks attached. OG did not want to increase risks that might have jeopardised the main project financing.

Changes in the credit rate of intermediary banks is a significant risk especially in countries like Italy where the banking sector is under strains. If the credit rate deteriorates the EIB can withdraw the capital and have a veto power on the choice of other financial institutions that could step in. It's evident what risk the financial equilibrium of the project financing would have faced.

\footnotetext{
${ }^{7}$ The financial costs of the debt are: upfront fee, commitment fee and interest fee. The upfront fee charged by EIB is sensibly lower than the one of commercial banks but the benefits were absorbed by extra transaction costs for the negotiation with EIB. The commitment fee of EIB is half of the one of commercial banks approximately 50 basis points - making OG to realize savings from the financial closing and diminishing over time until the end of construction phase. The interest fee is 90 basis points lower than the commercial one, and realized on the actual borrowed capital over 16 years - duration of the debt repayment.
} 
Figure 3 - the structure of the impact investing strategy as it was originally devised ${ }^{8}$

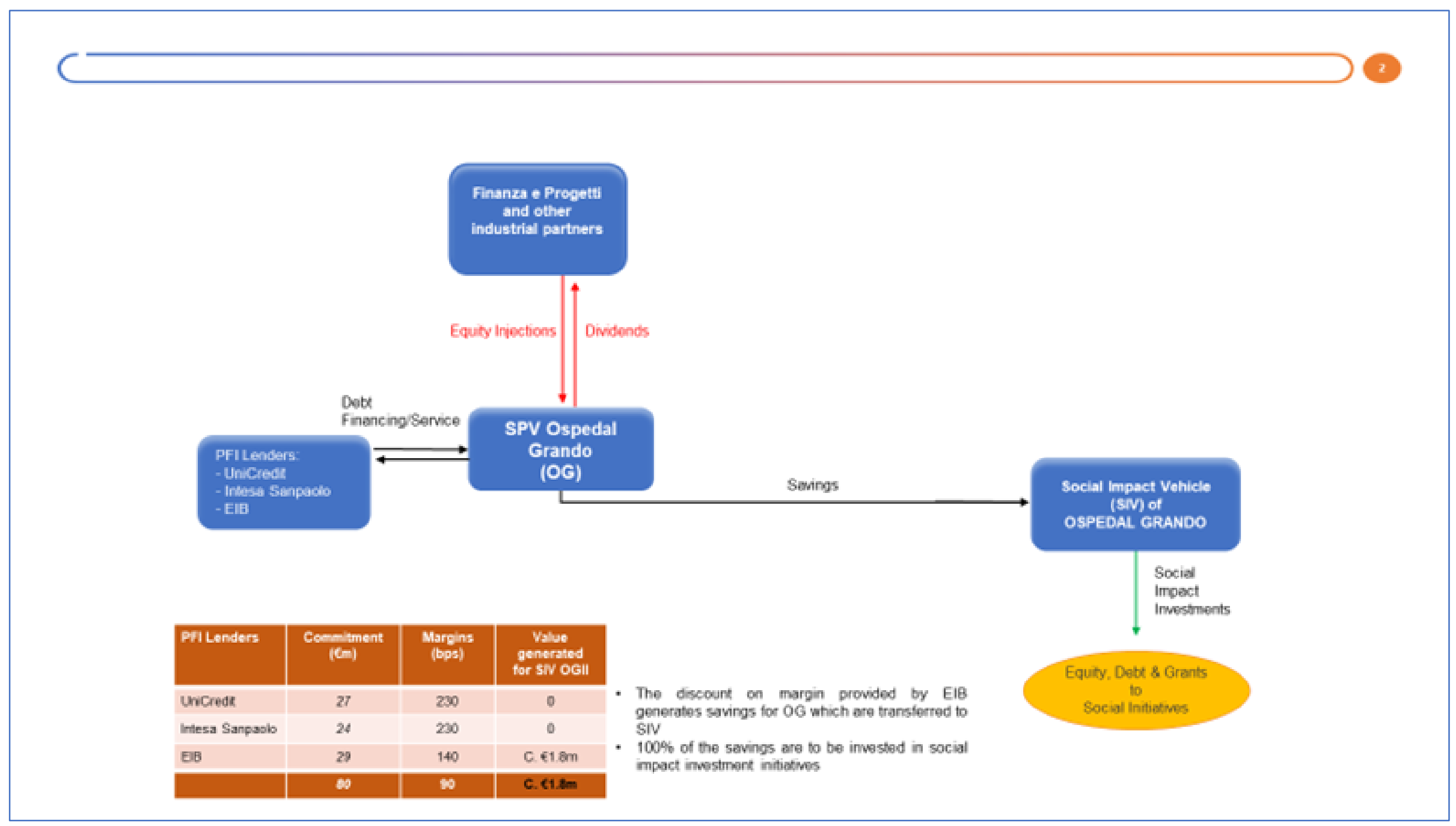

${ }^{8}$ Author's elaboration based on Lendlease's internal documentation 


\subsection{Shared Value' theory as interpretative framework}

To analyse the impact investing strategy of the Treviso case study we apply the 'Shared Value' framework developed by Michael Porter and Mark Kramer (Porter and Kramer 2011) as a blue print for the redefinition of the role of capitalism in society - an interpretation which has had much traction in international corporate circles.

Porter and Kramer developed the framework to address the legitimacy crisis that the private sector has undergone following the global financial crisis started in 2008. Such a loss of legitimacy is harmful for both business and society because it triggers governments' action against business and hinders economic growth. As the authors stated in clear letters in their first paper on the topic published in 2011, the crisis has proved that the neoliberal thinking that the main and only purpose of the company is to maximise short-term profits and shareholders' value as posited by Milton Friedman (Porter and Kramer 2011), is outdated and inadequate to address the challenges of the $21^{\text {st }}$ century. On the contrary, companies should pay attention to social values and their impact on society. Social and environmental impact shouldn't be understood as costs to be minimized, but as opportunities to create new markets. Therefore, companies should include social value creation in their business strategy as a source of efficiency, innovation and competitiveness. This is not a simple reconfiguration of Corporate Social Responsibility (CSR) nor a form of philanthropy as wealth redistribution, but an opportunity to transform current business models, and expand markets and profits. This, ultimately, will change capitalism and enhance its power to generate both economic and social value.

Companies can do so through three approaches that the authors identify as 'reconceiving products and markets', 'redefining productivity in the value chain', and 'enabling local cluster development'. Companies can adapt or develop new products to meet society's unmet needs. The second and third approaches target the network of suppliers and the community in which business operates.

We don't need to review the approaches in detail but it suffices to highlight the main points of the third approach - the one that fits the Treviso hospital case. Porter and Kramer argue that companies must invest in the communities in which they operate: address their structural weaknesses, develop their public assets, infrastructures and institutions, work in partnership with local stakeholders including the public sector and civil society. Their investment is repaid by having access to a greater pool of talents and bigger markets, and preventing future costs such as environmental degradation and unhealthy workforce.

On the other hand, 'Shared Value' theory as formulated by Porter and Kramer present interpretative limitations defining public sector's role, and identifying the challenges that any company would face building and managing multi-stakeholder governance, devising an appropriate investment strategy, and measuring social value. These are the four aspects that the case of the Treviso hospital helps us to consider providing hints to address them. 


\subsubsection{The public sector's role in impact investing}

Porter and Kramer assign to the public sector the role of setting the standards for social value creation, establish incentives for business, and monitor compliance with standards. These are certainly tasks for the public sector but do not exhaust its role. The case of Treviso hospital, on the contrary, supports the interpretation of the "Entrepreneurial State" as devised by Mariana Mazzucato (Mazzucato 2013). The public sector is not just a fixer of market failures as often portrayed in the neoliberal thinking that underpins Porter and Kramer, but shapes markets, builds market infrastructures, and invests to grow new markets often stepping in first, taking the highest risks and attracting private sector partners. Mazzucato's perspective is more effective in interpreting the role of the public sector in the Treviso hospital case. Figure 4 illustrates the role of EIB (public sector) in financing the impact strategy and devising its governance structure.

Firstly, the role of the EIB as investor has made the social impact investing strategy possible. Neither the companies nor the commercial banks were able to provide the capital to start the initiative. Secondly, the EIB helped designing the governance structure between the project finance and impact investing. Initially, the social impact vehicle was supposed to be a subsidiary of OG that would have collected the savings generated from the loan as equity capital, and invested on behalf of OG. This solution was problematic as the dependency of one company on the other one would have connected the risks of the project finance to the impact investments with a possible recourse claims on both sides. The EIB proposed, instead, to create a sister company called Ospedal Grando Impact Investing (OGII) capitalised by the shareholders of OG with the savings generated by the European loan. Doing so the impact investment stream was ring-fenced from the risk of project finance and vice versa. The EIB also provided the solution for the transfer of the savings generated by European loan to the impact investing vehicle. Such savings are returned to OG shareholders as special type of dividends - the so-called 'social impact dividends' in the contract of financing. Shareholders give mandate to $O G$ to transfer the dividends to the impact vehicle as these are generated in the form of 'social impact distributions'. So, de facto, it's an equity investment that OG shareholders make in a new company.

Finally - as a counterproof - the lack of government initiative in defining the boundaries of a new social impact investing market in Italy has been a source of misunderstanding and delays between the parties involved. Contrary to the UK, Italy does not have a clear policy and legal framework for impact investing, and lacks experts and intermediaries. So, the default position for companies willing to share value with the community is the traditional philanthropy or support to not-for-profit sector: for instance, financing the kindergarten for the hospital. Initially, the plan to set up an investment vehicle generating both financial and social returns was seen with suspicion by the partners. Actually, the first solution proposed was to transfer the savings to the public sector and cut its costs. But that would have defeated the purpose of impact investing by stifling, implicitly, the entrepreneurship displayed by the private sector, and certainly would have been a missed opportunity to generate further value for both 
shareholders and the community. Only the moral persuasion of EIB changed the situation and justified the impact investing strategy.

Hence the case of Treviso provides evidence against reductionist theories on the role of the public sector, showing not only the active role that it can have but also the necessity for its initiative and different shapes that it can take. In this project, a European institution took the lead, not the regional or national public authorities. Treviso project vindicates Mazzucato theory of government, and reminds the proponents of Shared Value theory and any other theory of public private partnership about the pivotal role of the public sector and the diversity of its manifestations. 
Figure 4 - Role of EIB (public sector) in financing the impact strategy and devising its governance structure ${ }^{9}$

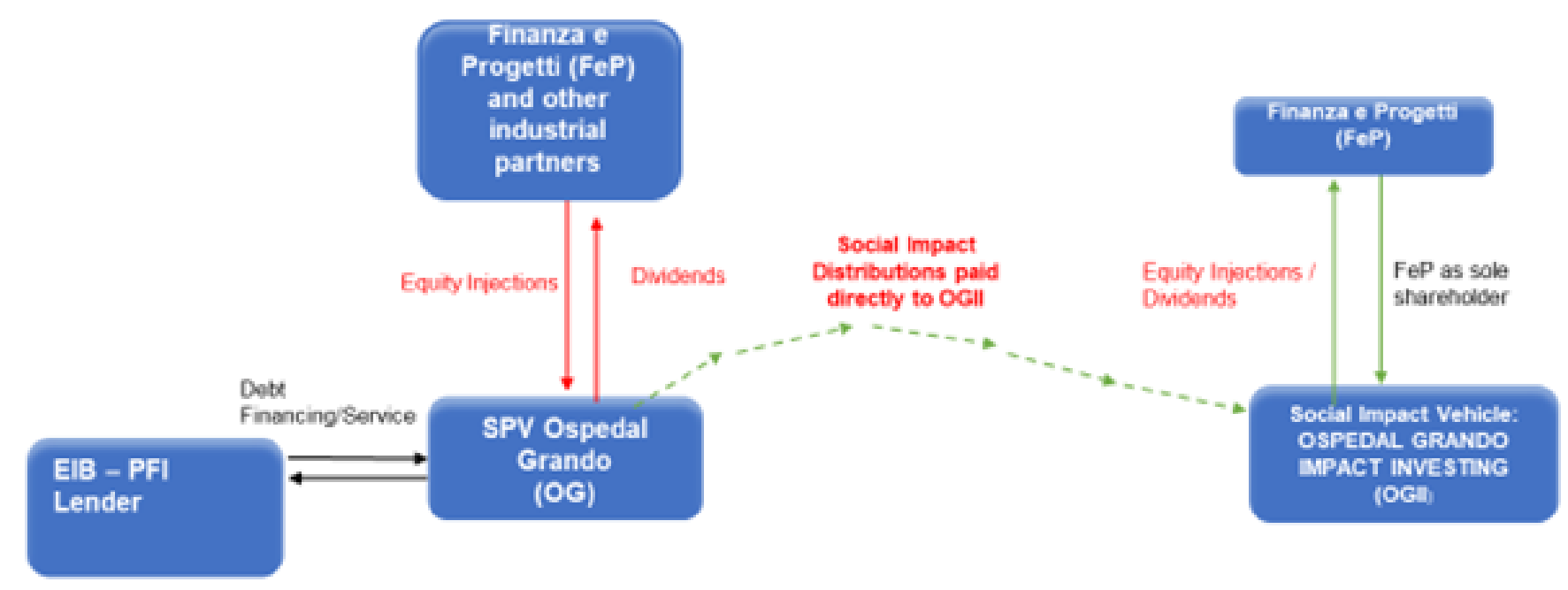

\begin{tabular}{|c|c|c|c|c|}
\hline PFI Lenders & $\begin{array}{l}\text { Commitment } \\
\text { (Cm) }\end{array}$ & $\begin{array}{c}\text { Bps } \\
\text { (margin) }\end{array}$ & $\begin{array}{c}\text { Value } \\
\text { generated } \\
\text { for siv OOIn }\end{array}$ & 3 \\
\hline EB & 29 & $140(90)$ & c. $61.8 \mathrm{~m}$ & $\begin{array}{l}\text { generate samings for OG which must be distributed } \\
\text { as 'Sociallmoact Distributions' to OGI }\end{array}$ \\
\hline
\end{tabular}

${ }^{9}$ Author's elaboration based on Lendlease's internal documentation 


\subsubsection{Multistakeholder Governance for impact investing}

Porter and Kramer acknowledge the role of coalitions: "Companies should try to enlist partners to share the cost, win support, and assemble the right skills. The most successful cluster development programs are ones that involve collaboration within the private sector, as well as trade associations, government agencies, and NGOs" (Porter and Kramer 2011). We agree with this point but the authors underestimate or ignore the challenges implied in multistakeholder action. Here we can draw on the ground-breaking research on collective action pioneered by the economist Marcur Olson in the field (Olson 1965). According to Olson, building a coalition of several and diverse partners is a public good - in the economic definition of the term. A cost-benefit analysis usually cannot justify such an effort. Furthermore, the costs are increased by the number and diversity of members in the coalition as the expected benefits are not the same. Certainly, they do not all respond to economic rationality alone, and it's naïve to posit that different stakeholders are due to join in a coalition because of an apparent opportunity to create public value. The politics of collective action is beyond what economic rationality can explain.

The project in Treviso showed clearly illustrated these challenges. The commercial banks were not able or willing to join for commercial reasons although they were attracted by the branding opportunities - especially in a wealthy province such as Treviso where the reputation of the banking sector is plummeting due to the collapse of the two main local banks. ${ }^{10}$ The philanthropic foundations were called to be part of such an initiative but had their own agendas and binding rules on how to use their resources. Most of Italian foundations struggle endorsing impact investing for both cultural and legal reasons - not to mention vested interests. The same case applies for potential co-investors approached in the process. The various stakeholders in the community did not have a unique and shared view, but identified different priorities for the impact investing strategy: projects and initiatives to invest.

Even in this case the interpretative framework of Porter and Kramer is not of great help due to their limited analysis of social dynamics. But we found a lead in a recent paper on impact investing that Giulio Pasi published for the Italian membership body of impact investors (Pasi 2017) - echoing the works of Elinor Ostrom on the governance of community assets (Ostrom 1990). Pasi argues that impact investing is a new field that brings together actors from all sectors forcing every player to reposition goals and patterns of behaviour. A natural alignment of professional cultures and values cannot be expected or taken as granted. The development of the field requires forms of brokerage and intermediation. Pasi's interpretation is validated by the choice of British Government that since 2000 has made impressive investments in new intermediaries to foster the impact investing market. ${ }^{11}$

In the case of the Treviso project, Ospedal Grando S.p.A (OG) tasked PlusValue (PV), as an external and knowledgeable broker, to map the local stakeholders identifying needs and

\footnotetext{
${ }^{10}$ Banca Popolare di Vicenza and Veneto Banca are bankrupt and have been sold to Intesa Sanpaolo for 1 euro each one (June 2017) with great financial loss of account holders and small investors.

${ }^{11}$ In Italy, the only financial intermediaries for impact investing with a track-record and significant size are Banca Prossima (subsidiary of Intesa Sanpaolo) UBI Banca, and OltreVenture (impact equity fund) with little or no support from government.
} 
opportunities, and devise an impact assessment methodology customised for the project. Contrary to the simplistic interpretation of Porter and Kramer, local stakeholders and civil society do not simply respond to leadership and opportunities offered by the private sector. Actually, the consultation of the community revealed that the initial assumptions for the impact strategy were wrong. While OG assumed that the main need in the community was in improving services for children and the elderly it turned out that the priority are young people: talent retention and new job opportunities. This simple observation explains the expectation of local stakeholders and civil society to be part of the strategic phase. For this purpose, Fondazione FITS! (a corporate foundation belonging to the Intesa Sanpaolo Bank Group) proposed to establish a Community Foundation to institutionalise the community's participation in the decision-making process. The proposal was not brought forward, but the investment policy of OGII, the impact investing vehicle, acknowledges the inputs of the community and commits to transparency of process and accountability on the final investment choices. It also foresees to bring in an external certifier to assess the realised impact. Transparency and accountability are key for community engagement. There is wide consensus in the scientific literature (Putnam et al. 1994; Fukuyama 2014).

Eventually the governance for the impact investing strategy in Treviso found a solution at the financial closing (July 2017): Finanza e Progetti (the majority shareholder of OG controlled by Lendlease) is in full control leaving the financing banks veto power on investment decisions, room for consultation to the community, opportunity to co-invest together with other investors, and relying on external experts for validation and impact assessment. It's the experience of the author confirmed by the Treviso project, that designing a multi-stakeholder governance system gathering a highly diverse membership of partners is the most challenging aspect of projects of this kind - more than raising capital. Moreover, it is a dynamic process that cannot be reduced to the simplicity and predictability of corporate governance rules.

\subsubsection{Impact investment policy}

What we see as the greatest contribution of 'Shared Value' theory by Porter and Kramer is the acknowledgement that investing in social value creation is a good investment even for profit making. Once agreed on that, the real difficulties start.

The Treviso hospital project proves how difficult it is to devise an effective investment policy. Figure 5 below summarises the agents and flows of the impact investment policy. The first challenge was to choose the legal form for the impact investing vehicle given the fact that the Italian legislation doesn't contemplate anything as such. In Italian law, a company is for profit, not for profit or a cooperative. ${ }^{12}$ So, for Ospedal Grando Impact Investing, it was set up as a company limited by shares and the impact mission was written in its Memorandum and Articles of Association. This makes impact considerations mandatory in every investment decision made by OGII Board of Directors. The localization of the social mission is another important element. The investment decisions must be in line with the PPP main project. So

\footnotetext{
12 New legislation on the reform of the third sector and social enterprise has just been approved by the Parliament, but the effective outcomes are far from being definitive.
} 
they have to be related to the fields relevant to the hospital such as health, education and social services, or the local community in Treviso or Veneto region. ${ }^{13}$ The legal rationale behind this choice is the comparison of OGII social mission to compensatory works often included in a PPP although not directly related to the core project. ${ }^{14}$ More broadly, such a convergence generates that a multiplier of value creation for the overall investment and local community, and justifies the discount on the loan of the EIB.

In respect to the market standards as defined by the international impact investing community and summarized in the final report of the Taskforce on social impact investing of G7: "The Invisible Heart of the Markets" (Social Impact Investing Taskforce 2014), OGII's mission and governance is only partially aligned. OGII has a mission-lock - in other words, the Board of Directors must take in consideration the impact dimension in every strategic decision and sharing it with the banks. ${ }^{15}$ the financing contract with the banks barred the board of directors from modifying the mission of OGII and the provisions on impact. On the other hand, OGII has a partial cap on both profit distribution and asset transfer. The cap lasts for the entire duration of the repayment of the project finance loan (i.e. 16 years). Until that point profits generated by successful investment must be reinvested in OGII. The company could be liquated on the $16^{\text {th }}$ years at the end of the repayment of the project finance loan. Before that date shareholders can sell their shares in OG to third parties with no obligation to take part in the impact strategy for the latter. However, they are due to compensate OGII in case of loss of expected capital generated by savings on the loan providing the equivalent capital. All these elements make OGII a straightforward for-profit enterprise with impact.

OGII is almost unique in Italy for its governance as well. In Italy, the governance of social enterprises is usually democratic drawing from the cooperative movement tradition. On the contrary, OGII has adopted an outright corporate governance leaving the full control to the shareholders; actually to the only shareholder: Finanza e Progetti (Lendlease, majority shareholders). The other shareholders of OG (holding 20\%) have forfeited their shares in favour of the former. In this model of governance OGII is a vehicle for venture capital investments with impact embedded in the core mission. ${ }^{16}$ OG shareholders' commitments to the impact investing strategy are ironclad as the savings from the financing are generated. This is formalised in a financing contract between OG and the banks. At the same time, this model justifies the direct investment of EIB as its benefits aren't privatised but reinvested by the shareholders in the community to generate further value for all parties involved.

All these elements make OGII a real novelty in the national and international panorama assimilating it to a form of corporate venture capital with positive social impact embedded in

\footnotetext{
${ }^{13}$ In Italian, article 4 of OGII's Memorandum of Understanding: "Partecipazione ad iniziative economiche in Italia nel settore sociale o che abbiano finalità di impatto sociale, ivi incluso a titolo meramente esemplificativo iniziative riguardanti la fornitura di servizi socio-sanitari, assistenziali, welfare, culturali o didattici ovvero di sostegno all'ambiente e al turismo eco-sostenibile"

${ }^{14}$ Interpretation of Bonelli Erede, the law firm assisting EIB.

${ }^{15}$ Only EIB finances the impact investing vehicle but all the banks involved in the project financing of the main project, are included in the impact investing decisions.

${ }^{16}$ It's the view of Sir Ronald Cohen (Chairman of the G8 Taskforce on social impact investing) reiterated in numerous occasions by other early impact investors such as Luciano Balbo (OltreVenture) that impact investing is a declination of venture capital applied to the social sector (Vecchi and others 2015).
} 
its mission (Growth Capital Ventures 2017). It should not be considered a mature model for impact investing and entrepreneurship, but an experimental hybrid (Venturi and Zandonai 2014). In any case, its success would prove that impact investing can be a component of a new business strategy that aligns private and public interest, and is suitable for mainstream and sizeable companies and investors. 
Figure 5 - Agents and flows of the impact investment policy ${ }^{17}$

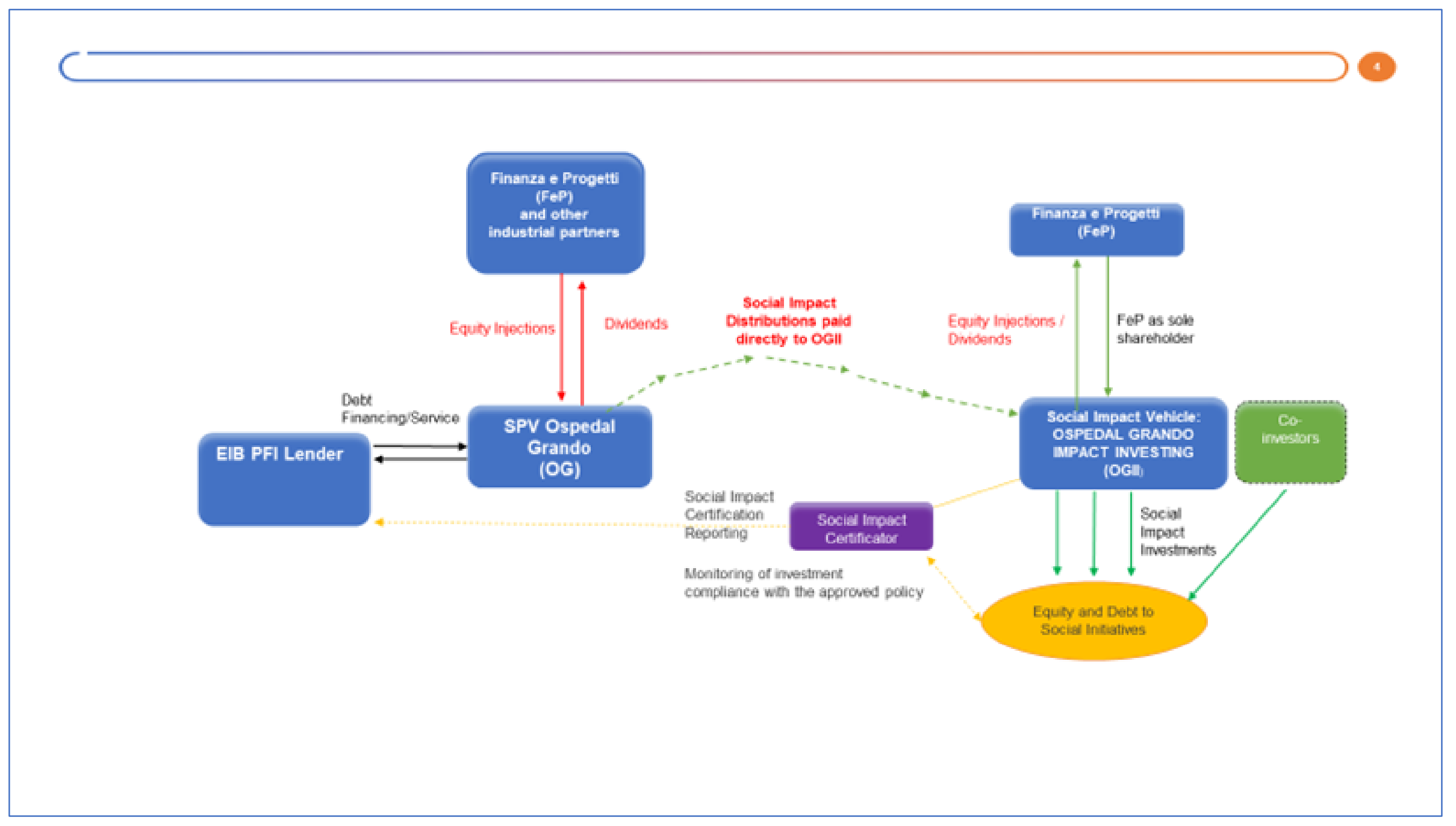

${ }^{17}$ Author's elaboration based on Lendlease's internal documentation 


\subsubsection{Impact assessment}

Finally, Porter and Kramer recognize the importance of measuring impact - they call it social value - and collection of data to build a baseline for market growth. This is true without a doubt, but the researchers underestimate the difficulty of doing so. The measurement of impact or social value is not as straightforward as measuring financial value. It is based on decisions that are affected by the different stakeholders who are involved, and is sector specific. Measuring results in health is quite different than education. Impact measurement in the UK exemplifies the challenge. Government has been fostering impact measurement for almost 20 years and, in 2013, put it into law with the Social Value Act requiring social impact measurement in public procurement for all public services. Despite the efforts, the potential and some success, social impact measurement is still far from becoming an exact science, as public assessment for the British Government has recognised (Young 2014).

In the Treviso project, PlusValue has been contracted by Ospedal Grando (OG) to put in place a framework for impact assessment following the mapping of stakeholders and their needs. The investment policy of OGII (the impact investing vehicle of $O G$ ) requires an impact assessment based on the mapping, consultation with the community stakeholders and the international standards applied by Lendlease to every project in the world (Lendlease 2016). All the investors have demanded in written form in the financial contracts that the assessment is taken regularly to evaluate achievements against targets, the perception of the local community and stakeholders, and possible improvement and adaptations to increase value generation. The evaluation hasn't started yet at the time of writing the paper as the financial closing was in July 2017.

The impact assessment is based on the Social Return on Investment (SROI) approach, the international standard method to account for both monetizable and non-monetizable impact (Social Value UK 2012). It's the basis to devise a comprehensive assessment framework system to collect, monitor, and analyse socio-economic impact data, both from available databases and crowdsourced data. It includes a set of socio-economic goals (e.g. increased well-being of the local population, jobs and enterprises created, increased social capital for defined social groups etc.); a set of impact indicators (e.g. number of new jobs and enterprises, increase in salaries, investment in local area, reported satisfaction of local citizens, number of people using public spaces, etc.); methods and tools to collect, store and share data (e.g. subjective/self-reported indicators vs. objective indicators, existing data vs. new data, desk research vs. interviews, surveys, crowd-sourcing, social media analysis). The SROI is to be matched with an experimental online open data platform to track and analyse social media activities related to the project. Social media data are processed through a mix of natural language analysis, network analysis, geo-referencing and machine learning developed by Human Ecosystems, to provide a thorough assessment of the impact of the project. A similar approach has already been successfully tested and implemented in Bologna (Human Ecosystem 2015). ${ }^{18}$

\footnotetext{
${ }^{18}$ For further information on the methodology see https://www.he-r.it/
} 
The second observation to make when comparing Shared Value theory with the actual development of the impact project in Treviso is the non-linearity of the process of impact assessment. Porter and Kramer present social value recording as a mere fact of accounting, but in reality the complexity of interactions, time lapses, unforeseen causes and consequences make the impact assessment often impossible at least in terms of causal attribution and monetary equivalent. Looking at it from a mere corporate prospective, how can an investment be deemed successful or not if its contribution to the bottom-line cannot be defined? Usually the only certain attribution is the expenses, that makes it like a charitable initiative. A concrete example related to Treviso can illustrate the point. One of the initiatives that could be the target of OGII action is the plan to create a new international Faculty of Medicine in the premises of the hospital, bringing together higher education and practice to attract students from all over the world. ${ }^{19}$ This project would increase the value of the overall investment in the hospital but measuring the return on investment for the developer is not evident and might not be done exhaustively.

\footnotetext{
${ }^{19}$ Interview with Francesco Benazzi, CEO of ULSS Treviso (Provincial NHS authority)
} 


\section{Conclusions}

The analysis of the case of the project in Treviso has been a unique opportunity to test the potential of impact investing to lead a corporation to move beyond the current mindset in which the business model is reduced to short-term profit maximisation, erasing any awareness of interdependencies between the company and all the other stakeholders that populate the environment in which it operates. Instead, the Treviso case study embraces a non-zero-sum approach that not only recognizes but capitalises on such interdependencies to increase value creation aligning public and private interests.

Concretely the results generated by the project are multiple and it's useful to recapitulate them to show the full picture as illustrated in Figure 6. First of all, the case study has tested and proved that the impact investing strategy has a transformative power in infrastructural projects generating new resources to increase the overall value of the investment. By including impact investing in the plan of the PPP for the new hospital in Treviso Ospedal Grando (OG), the SPV created by Lendlease and its industrial partners to carry out the concession contract to design, finance, build and manage the hospital, was able to secure $29 \mathrm{~m}$ euros loan from the European Investment Bank (EIB) at a discount price compared to the market rate. The optimization of the project financing has generated an extra $1.8 \mathrm{~m}$ euros that OG shareholders use in its entirety to capitalise a new vehicle - named Ospedal Grando Impact Investing (OGII) - established to invest in entrepreneurial and financial initiatives that combine both financial and social value creation. That will support initiatives that expand the services of the hospital and opportunities in the local community.

If the investment phase works as well it will generate a sustained positive feedback that will induce further investments in OGII, more capital for enterprises, more jobs, better services for the community and a greater commitment of the community stakeholders in sustaining the positive cycle. This would be a new frontier for sustainability and resilience. Certainly, we expect Lendlease to replicate the model tested in Treviso in other and larger projects and this is already under way with the next regeneration project for the Arexpo Milan for which Lendlease has been invited to bid. ${ }^{20}$

Secondly, the project in Treviso has offered to EIB a framework to realise the ambition of the Junker Plan to relaunch investments in strategic infrastructures across Europe proving how to address societal impact in the investment policy of the European bank. This result has been acknowledged in the official communication of EIB and could be replicated across Europe with an impact on up to 0.5 trillion euros which is the investment target of the reviewed Juncker Plan (European Commission 2016). The project has also identified areas of improvement in the investment policy of the European bank to increase its impact and power to leverage private capital. Actually, the EIB leadership can induce private banks and investors to follow the example. In the case of Treviso, we have seen the influence that EIB has had on UniCredit Group and Intesa Sanpaolo, the two main Italian banks, in getting them move beyond their comfort zone although the concrete results in terms of extra capital for the impact strategy did not materialise due to bank's policies. Those policies can be improved in the future to

${ }^{20}$ See http://www.arexpo.it/en/homepage 
mobilise more commercial partners. This is a priority. British Government established a working group to engage insurance groups and pensions funds (Independent Dormant Asset Commission 2017), and was followed by the European Commission (High-Level Expert Group on Sustainable Finance 2017). The market is mature for the main investors to step in and embed impact investing principles in their mainstream operations.

The project has also revealed a flaw in the funding system which could be addressed by ElB leadership. In Treviso, we were not able to mobilise the traditional public and philanthropic resources - e.g. bank foundations, corporate foundations, structural funds. The funding environment for entrepreneurship and innovation is still very fragmented. The one for impact investing and entrepreneurship is even more scattered in multiple, small initiatives that do not create a critical mass. Funders pursue individual agendas and there are no incentives to join forces. Moreover, the hybridization of commercial practice and philanthropic resources faces cultural and legal barriers that represent a real obstacle for impact investing. Projects like OGII in Treviso exemplify the emergence of alternatives but cannot scale without the intervention of policy-makers to address structural shortfalls.

Thirdly, the project in Treviso has become an opportunity to devise new legal solutions to embed impact investing principles in current business practices even in a country like Italy where government action has been deficient in developing the market infrastructure. The law firms that assisted OG and the banks were creative in devising legal arrangements that ringfenced the risks of the project finance from the ones of impact investing creating two separate companies, but aligned their mission. OG and OGII are sister companies with almost the same shareholding structure (Finanza e Progetti holds $80 \%$ of OG shares and $100 \%$ of OGII shares) and the commitment to invest in projects related to the hospital and the local community is spelled out in the Memorandum and Articles of Association of OGII. Moreover, an ingenious solution has been devised for the transfer of the savings due to the loan to the impact investing vehicle: the savings are in principles dividends for OG shareholders which have mandated OG to transfer to OGII as 'Social Impact Distributions' they are generated during the course of the project (16 years). This is an elegant solution that avoids any risk of recourse, and turns the operation into a form of corporate venture capital with impact.

However, the model designed still has a problem: EIB releases the capital step by step and savings on the financing of the project are realized over 16 years. This means that OGII, in principle, would be capitalised in full not before 2033 and only then it would be able to invest. To implement the impact investing strategy from the beginning of the construction phase (2017) there is a need to anticipate the capital against the future savings. OG shareholders could advance the capital ${ }^{21}$ and get repaid as the savings are realised. The challenge for the industrial partners would be to price the risk and define the expected return. In any case the remuneration would be high and arbitrary. Therefore, Lendlease has opted for a bridge-loan by the banks as professional lenders. The proposal is under discussion with the commercial banks. ${ }^{22}$ The solution of this point is relevant for the evolution of the market. The discount on

\footnotetext{
${ }^{21}$ Italian legislation allows for 'prestito soci' a loan between shareholders or partners in business.

22 Interview with Francesco Mandruzzato, CEO of OG and head of PFI at Lendlease Italy
} 
the pricing of the loan would be a proxy to measure the banks' commitments to impact ${ }^{23}-a$ method developed and piloted by Engaged Investment Itd (Evenett and Richter 2011). There is a further point which is also not solved yet. Delays or missed payments due to issues with main project finance will have a negative impact on the release of savings. Who takes the risk and pays for the extra costs? Lendlease's proposal is that the lent capital would be swapped for shares of OGII in proportion of the loss turning the lender into a shareholder. For the time being the agreement on the bridge-loan hasn't been agreed between OG and the banks. In any case this is an ad hoc solution. So even this situation requires greater attention to develop structural solutions for the market.

Finally, the hospital of Treviso is the first project of this scale and complexity to our knowledge in which the private sector partners - with no request from the public counterpart - have not only committed to an impact investing strategy, but have also included an independent assessment of the outcomes and the inclusion of the main community stakeholders in the whole cycle, an even considered the use of experimental methods based on online tools. Such a commitment is formalised in the investment policy of OGII and financial contracts between the banks and OG.

The Shared Value theory as an interpretative framework for private sector's initiative in aligning its values to the ones of society, has been helpful to analyse the structure of value generated by the project in Treviso. At the same time, we pointed out the limits of the theory compared to developments in the field. As argued above Porter and Kramer's model shows severe limitations on multiple points: in identifying the role of the public sector as co-leader in building the market infrastructure of impact investing and early investor; the complexity of building multi-stakeholder coalitions that bring together stakeholders from different sectors in a join action to pursue both their individual interests and public good; the challenges in devising an investment policy which meets the profit-making mission of a company with the aspiration to generate positive impact in the community. Such a balance is far from evident. Finally, the Shared Value theory underestimates the different methodology for assessing social values compared to monetary value. The former is far from financial accounting and quantifiable measurements.

These remarks question the validity of the Shared Value theory - although we acknowledge the contribution of the intuition underpinning the theory and its ability to influence the course of theory and practice of capitalism - and should be taken as new starting points for future research in the field. Our conclusion is the need to move beyond a corporate perspective since companies are just one of the agent typology in a highly diverse environment. The company is not a closed system but is an element of a complex and dynamic system. Hence Impact investing theory requires a system perspective that embraces a multistakeholder approach and aims at redefining the terms and practice for long term socioeconomic sustainability and resilience (Addarii and Lipparini 2017).

${ }^{23}$ An approximate estimate of the interest fee is around 6\% (source: Francesco Mandruzzato) 
Figure 6 - Summary of the finalised impact investing mode ${ }^{24}$

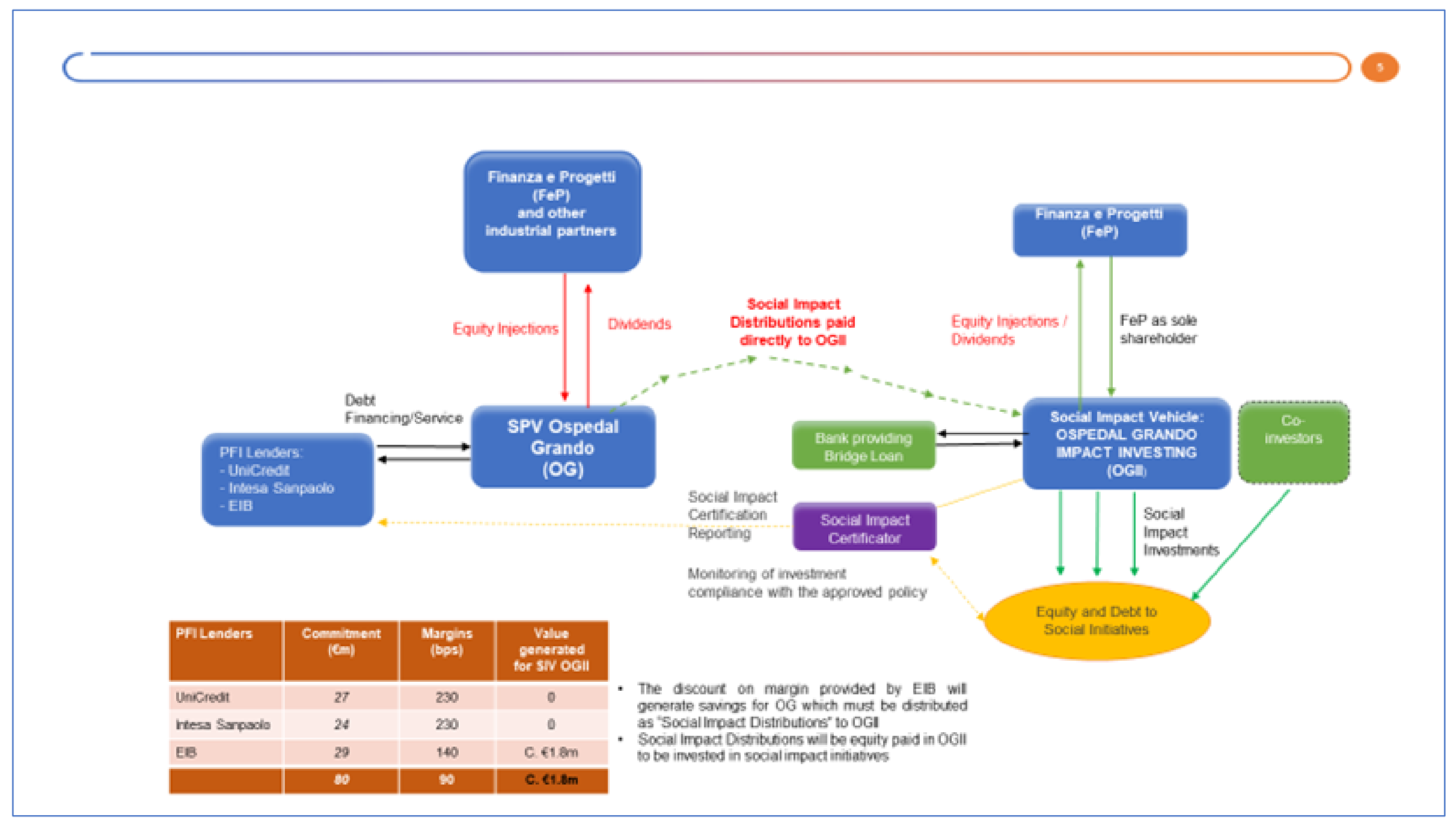

${ }^{24}$ Author's elaboration based on Lendlease's internal documentation 
Bibliography

Addarii, F., Lipparini, F., 2017. Vision and Trends of Social Innovation for Europe. European Commission.

Advisory panel to mission-led business review, 2016. On a Mission in the UK Economy. Current state of play, vision and recommendations from the advisory panel to the Mission-led Business Review. Department for Digital, Culture, Media \& Sport HMRC

Agostini, C., Lisi, V., Natali, D. and Sabato, S., Balancing protection and investment: structural reforms in five countries. ETUI 2016

Amatucci, F., Vecchi, V. and Germani, A., 2007. Il project finance in sanità: un'analisi delle caratteristiche economiche e finanziarie. L'aziendalizzazione della sanità in Italia: rapporto OASI 2007, pp.1000-1032.

Augé, M., 2002. In the metro. University of Minnesota Press.

Barlow, J., Roehrich, J. and Wright, S., 2013. Europe sees mixed results from public-private partnerships for building and managing health care facilities and services. Health Affairs, 32(1), pp.146-154.

Bridges Ventures, 2015. The Bridges Spectrum of Capital

Carbonaro, G., 2017. Research for REGI Committee - Public Private Partnerships and Cohesion Policy. European Parliament

Christensen, C.M., 2013. The innovator's dilemma: when new technologies cause great firms to fail. Harvard Business Review Press.

Crane, A., Palazzo, G., Spence, L.J. and Matten, D., 2014. Contesting the value of "creating shared value". California management review, 56(2), pp.130-153.

Daggers, J. and Nicholls, A., 2016. The landscape of social impact investment research: Trends and opportunities. SBS, Oxford.

Dhéret, C. and Fransen, L., 2017. Social Investment first! A precondition for a modern Social Europe. EPC Issue Paper No. 82, March 2017.

Ethex, 2017. Understanding the Positive Investor. A research study revealing the level of interest in positive investment in the United Kingdom.

Evenett, R. and Richter, K, 2011. Report - Making Good in Social Impact Investing. Opportunities in an Emerging Asset Class.

European Commission, 2003. Guidelines for Successful Public - Private Partnerships. 
European Commission, Europe 2020 Flagship Initiative Innovation Union. COM(2010) 546

European Commission, Social Business Initiative Creating a favourable climate for social enterprises, key stakeholders in the social economy and innovation. COM(2011) 682

European Commission, 2011. Empowering People, Driving Change: Social innovation in the European Union. ed BEPA

European Commission, 2013. Powering European Public Sector Innovation: Towards a New Architecture. Report of the Expert Group on Public Sector Innovation.

European Commission, 2014. Social Innovation: A Decade of Change. ed. BEPA

European Commission, Towards Social Investment for Growth and Cohesion - including implementing the European Social Fund 2014-2020. COM(2013) 83

European Commission, An Investment Plan for Europe. COM(2014) 0903

European Commission, 2016. Strengthening European Investments for jobs and growth: Towards a second phase of the European Fund for Strategic Investments and a new European External Investment Plan. COM(2016) 581

European Investment Bank, 2017. Juncker Plan: EIB finances better healthcare in the Veneto Region. (Press release)

Ferrera, M., 2005. The Boundaries of Welfare. European Integration and the New Spatial Politics of Social Protection, Oxford University Press

Fransen, L., Reviglio, E., Watson, J. Report of the High-Level Taskforce on Investments in Social Infrastructures (to be published by the end of 2017)

Fukuyama, F., 2014. Political order and political decay: From the industrial revolution to the globalization of democracy. Profile Books

Growth Capital Ventures, 2017. Investing in Breakthrough Corporate Venture Capital

Hall D. Why Public-Private Partnerships Don't Work. The Many Advantages of the Public Alternative. PSIRU, Greenwich University

High-Level Expert Group on Sustainable Finance, 2017. Financing a Sustainable European Economy, Interim Report, July 2017, European Commission

Human Ecosystem, 2015. Human Ecosystem Bologna Report. http://dati.comune.bologna.it/file/hub-report eng.pdf

Independent Dormant Asset Commission, 2017. Tackling Dormant Assets: recommendations to benefit consumers and society - Report to Government. Department for Digital, Culture, Media \& Sport, HMRC 
International Bank for Reconstruction and Development and The World Bank 2015. Report on Recommended PPP Contractual Provisions. The World Bank Group, Washington

Italian National Advisory Board, 2014. La Finanza che Include: Gli Investimenti ad impatto sociale per una nuova economia. Rapporto Italiano della Social Impact Investment Task Force istituita in ambito $\mathrm{G} 8$

Jacobs, M. and Mazzucato, M. eds., 2016. Rethinking capitalism: economics and policy for sustainable and inclusive growth. John Wiley \& Sons.

Jenson, J., 2015. Social innovation: redesigning the welfare diamond. In New Frontiers in Social Innovation Research (pp. 89-106). Palgrave Macmillan UK.

Leveson- Gower, H. 2017. Public Infrastructure and Private Finance. Can there be a happy ever after? CECAN Report June 2017, New Economic Knowledge Services

Lendlease, 2016. GRMRs Global Minimum Requirements - Environment, Health \& Safety. Lendlease, Sydney

Lipparini, F., Phillips, S., Addarii, F., Johar, I. March 2015. From good to growth. Promoting social investment and public good to stimulate the European economy. Young Foundation, London

Lipparini, F., Phillips, S., Addarii, F., Johar, I. 2015. From good to growth. Promoting social investment and public good In Investing in Long-Term Europe. Relaunching Fixed, Network and Social Infrastructures ed. by Garonna, P., Reviglio E. (pp. 267-290). Luiss University Press

Martin M., 2013. Status of the Social Impact Investing Market: A Primer. Prepared for the UK Cabinet Office. Crown, Geneva

Mazzucato, M., 2013. The Entrepreneurial State: Debunking Public vs. Private Sector Myths. Anthem Press

Misuraca, G., Kucsera, C., Lipparini, F., Voigt, C. and Radescu, R., 2016. Mapping and Analysis of ICT-enabled Social Innovation initiatives promoting social investment in integrated approaches to the provision of social services: IESI Knowledge Map 2015 (No. JRC101042). Joint Research Centre (Seville site).

Morel, N., Palier, B. and Palme, J., 2009. What future for social investment? Stockholm: Institute for Futures Studies.

OECD, 2015, Social Impact Investment: Building the Evidence Base.

Olson, M., 1965. The Logic of Collective Action. Public Goods and the Theory of Groups. Harvard University Press.

Ostrom, E., 1990. Governing the Commons. The Evolution of Institutions for Collective Action Cambridge University press. 
Pasi, G., 2015. Fare per capire: UBI Banca propone il suo Project Finance a Impatto Sociale. Cade la retorica dell'impact investing mentre cresce l'attenzione verso il mercato del secondo welfare. SecondoWelfare 01 february 2016 (online)

Pasi, G. ed. by, 2017. Modelli di Risposta ai Nuovi Bisogni Sociali e Possibili Scenari di Riforma, Social Impact Agenda per I'Italia, Rome

Porter, M.E. and Kramer, M.R., 2011. The big idea: Creating Shared Value-how to reinvent capitalism and unleash a wave of innovation and growth. Harvard Business Review, 89(1-2).

Putnam, R.D., Leonardi, R. and Nanetti, R.Y., 1994. Making democracy work: Civic traditions in modern Italy. Princeton university press.

Rittner, T, Barbash, M., Kramer, K, 2017. Urban Revitalization and Impact Investing: Unlocking the Potential for an Impact Investing \& Development Finance Agency Urban Revitalization Collaboration. March 2017, CDFA Impact Investing White Paper Series

Salamon, L.M., 2014. Leverage for good: An introduction to the new frontiers of philanthropy and social investment. Oxford University Press, USA.

Salamon, Lester M., 2014. New frontiers of philanthropy: A guide to the new tools and new actors that are reshaping global philanthropy and social investing. Oxford University Press, USA

Sanders, B., Mulgan, G., Ali, R., Tucker, S. 2007. Social Innovation: What it is, why it matters, how it can be accelerated. Oxford University

Social Impact Investment Taskforce, 2014. Impact Investment: The Invisible Heart of Markets. Harnessing the power of entrepreneurship, innovation and capital for public good

Social Value UK (2012). A Guide to Social Return on Investment.

Stiglitz, D.J., 2009. Moving beyond market fundamentalism to a more balanced economy. Annals of public and cooperative economics, 80(3), pp.345-360.

The Economist Intelligence Unit, 2016. Motivated by impact: A new generation seek to make their mark.

UN DESA, 2014. World Urbanization Prospects - Revision. United Nations

Vecchi., V, Casalini, F., Balbo, L., Caselli, S. 2015. Impact Investing: a new asset class or a societal refocus of Venture Capital? Impact Investing Lab, SDA Bocconi School of Management

Vecchi, V., Leone, V. 2016. Partnership Pubblico Privato. Una guida manageriale, finanziaria e giuridica, Egea, Milano

Venturi, P., Zandonai, F., 2014. Ibridi organizzativi. L'innovazione sociale generata dal Gruppo cooperativo Cgm, II Mulino, Bologna.

Young, L. 2014. Social Value Act Review Report to Government. HMRC 
Wolanski, F. 2017. Nuovo ospedale di Treviso: Zaia posa la prima pietra - Cronaca - Tribuna di Treviso. [online] Tribuna di Treviso. Available at: http://tribunatreviso.gelocal.it/treviso/cronaca/2017/06/16/news/apre-il-cantiere-300park-gia-per-aprile-1.15499561 [Accessed 25 Aug. 2017] 